Zimna Aleksandra, Wróblewski Hubert. Prejudice against psychiatry. Journal of Education, Health and Sport. 2021;11(8):204-208. eISSN 2391-8306. DOI http://dx.doi.org/10.12775/JEHS.2021.11.08.020

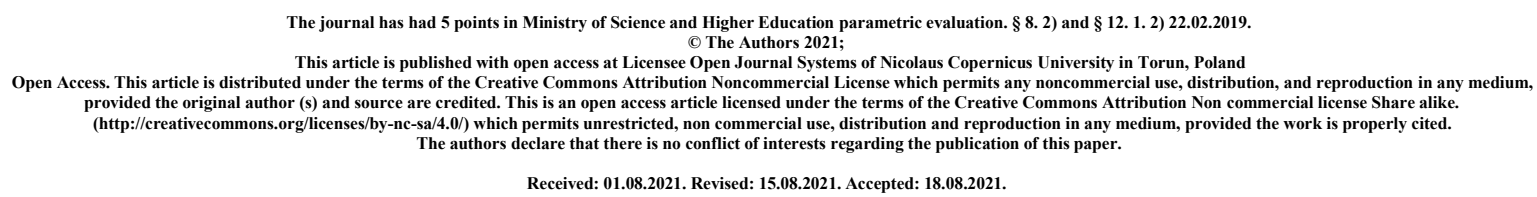

\title{
Prejudice against psychiatry
}

\author{
Aleksandra Zimna, Hubert Wróblewski
}

\section{Faculty of Medicine, Medical University of Lublin}

\begin{abstract}
Introduction: There are many stereotypes in society about psychiatric patients and the diseases they suffer from. Psychiatrists themselves are often treated with reserve by society. They cause respect among patients and, at the same time, fear of having to visit.

Aim of the study: The aim of the study is to analyze the attitude of society to psychiatric patients, their diseases and psychiatrists. Methods: The results of the study were obtained on the basis of an online survey.

Results: 138 respondents took part in the survey, $81.2 \%$ were women and $18.8 \%$ were men. As many as $22 \%$ of respondents do not know who a psychiatrist is, confusing his competence with a psychologist. Over $40 \%$ believe that they would feel more stressed before visiting this doctor than with any other specialist, $31.9 \%$ associate visiting a psychiatrist with decreased self-esteem, difficulty in finding a permanent job (21\%) and perceive them as embarrassing (70\%) More than half of the respondents admit that they would conceal this fact from the employer. As many as $62.3 \%$ of the respondents would not enter into a partnership with a person receiving treatment from a psychiatrist.

Conclusions: On the basis of the obtained results, it can be noticed that the society is prejudiced against psychiatric patients, diseases in this field and specialist doctors themselves. Fear, insecurity, and withdrawal can be conditioned by an inadequate level of knowledge. However, as the years go by, society's confidence in psychiatrists is growing, to comfort.
\end{abstract}

Key words: psychiatrist; mental illness; psychiatrist; prejudice; stereotype

Wstęp: W społeczeństwie pokutuje wiele stereotypów dotyczących pacjentów leczących się psychiatrycznie i chorób, na które cierpią. Negatywnym skutkiem dystansowania się do 
chorych psychicznie jest tendencja do nieakceptowania pacjentów jako pełnoprawnych uczestników życia społecznego. Ta dyskryminacja utrudnia pacjentom powrót do zdrowia i uczestniczenia w społeczeństwie. Sami psychiatrzy są nierzadko traktowani przez społeczeństwo $\mathrm{z}$ dystansem. Wśród pacjentów wywołują respekt i jednocześnie obawę przed koniecznością wizyty.

Cel: Analiza stosunku społeczeństwa do pacjentów psychiatrycznych ich chorób oraz psychiatrów była przedmiotem naszego internetowego badania ankietowego.

Materiały i Metody: Wyniki badania uzyskano na podstawie przeprowadzonego internetowego badania ankietowego.

Wyniki: W ankiecie wzięło udział 138 respondentów. Przeważającą część (76,1\%) stanowiły kobiety zaś $23,9 \%$ mężczyźni. W większości były to osoby młode, gdyż 54,7\% mieściło się w przedziale wiekowym 19-29 lat. Najmniejszy udział w ankiecie miały osoby będące w wieku poniżej 18 lat.

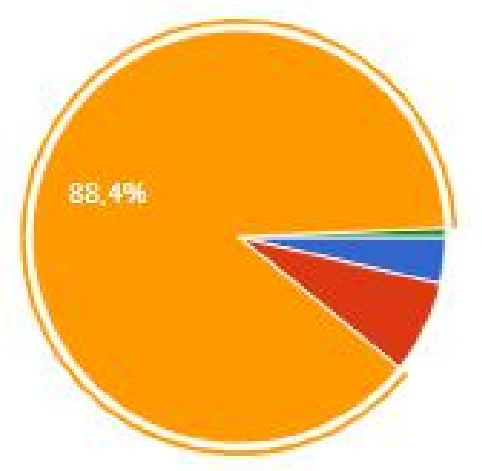

to pojẹcie tożsame z psychologiem i

psychoterapeuta

od psychologa odróżnia go możliwość

wypisywania recept

lekarz specjalista

może nim być psycholog i

psychoterapeuta po ukończeniu

dodatkowego kursu

Wykres 1.

Aż 11,6\% ankietowanych nie wie,że psychiatra to lekarz myląc jego kompetencje z psychologiem lub psychoterapeutą (Wykres 1.).

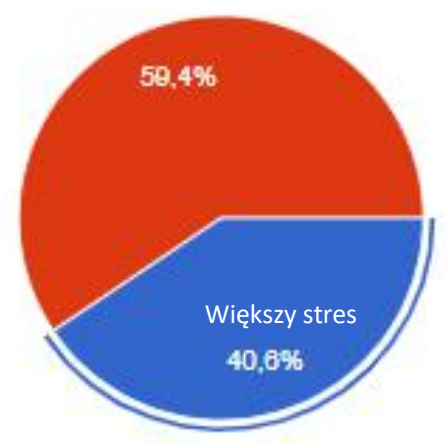

Wykres 2.

Ponad $40 \%$ uważa,że odczuwałaby większy stres przed wizytą u tego lekarza niż u jakiegokolwiek innego specjalisty (Wykres 2). 
$31,9 \%$ ankietowanych wiąże uczęszczanie na wizyty do psychiatry ze spadkiem samooceny, trudnością $\mathrm{W}$ znalezieniu stałej pracy (21\%) i postrzega je za krępujące $(69,6 \%)$.Ponad połowa ankietowanych wyznaje,że zatajałaby ten fakt przed pracodawcą (Wykres 3).

\section{Czy myślisz,że uczęszczanie na wizyty do psychiatry:}

138 odpowiedzi

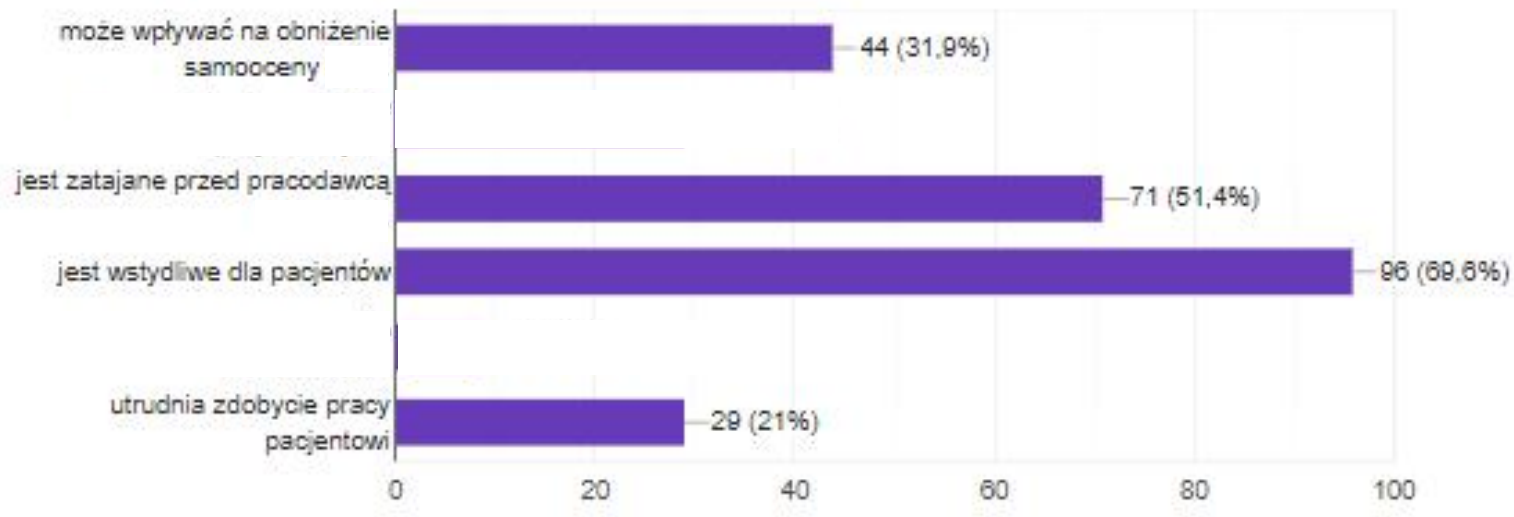

Wykres 3.

Pokrzepiający jest jednak fakt,iż żadna spośród ankietowanych osób nie zamyka się na skorzystanie z pomocy psychiatry w przyszłości (Tabela 1).

\begin{tabular}{|l|l|}
\hline \multicolumn{2}{|l|}{ Czy korzystałeś kiedyś z pomocy psychiatry? } \\
\hline Warianty odpowiedzi & Uzyskany procent odpowiedzi \\
\hline Tak & $17,4 \%$ \\
\hline Nie porzystającą z pomocy & $54,3 \%$ \\
\hline $\begin{array}{l}\text { Znam osobę } \\
\text { psychiatry }\end{array}$ & $28,3 \%$ \\
\hline $\begin{array}{l}\text { Nigdy nie poszłabym/poszedłbym do } \\
\text { psychiatry }\end{array}$ & 0 \\
\hline
\end{tabular}

Tabela 1. 


\section{Czy pleć lekarza psychiatry stanowiłaby Twoje kryterium wyboru?}

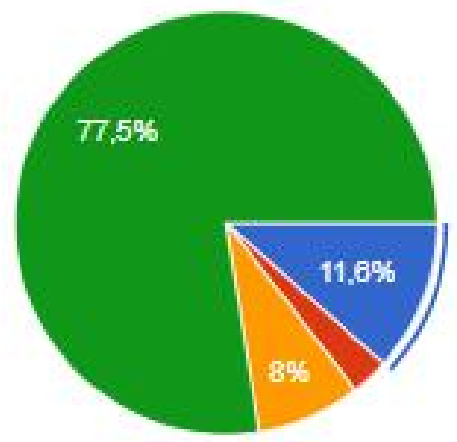

wybrałabymiwybrałbym lekarza tożsamej ploi

miałabym/miałbym viẹksze zaufanie do męzczyzny

miałabym/miałbym wiẹksze zaufanie do kobiety

nie stanowitoby to mojego kryterium wyboru

Wykres 4.

Dla 22,5\% odpowiadających płeć lekarza odgrywałaby dużą rolę. Preferowanym rozwiązaniem byłby wybór specjalisty tożsamej płci $(11,6 \%)$ (Wykres 4).

Dyskusja: Ostatni wiek to stopniowo postępujące zmiany w postrzeganiu osób chorych psychicznie przez społeczeństwo. Niegdyś choroba psychiczna była rozumiana w kontekście fatum, opętania przez złe moce czy innych zjawisk nadprzyrodzonych lub magicznych konotacji. Aktualnie zaś ujmowana jest w kategorii przypadłości somatycznej co jest wynikiem ciągłej edukacji społeczeństwa. Według Sutovica stygmatyzacja to połączenie ignorancji i strachu co stanowi podłoże do tworzenia zakorzenionych mitów i uprzedzeń. Głównie dotyczy to pacjentów chorujących na schizofrenię. Zjawisko dyskryminacji społecznej jest szczególnie trudne dla pacjentów z niepełnosprawnością intelektualną. Nierzadko są oni postrzegani jako niebezpieczni, nieodpowiedzialni co prowadzi do ich izolacji, bezdomności, problemów ekonomicznych (1). W badaniu Kochańskiego i wsp. z 2018 roku, w którym ankietowani stanowili grupę 232 polskich lekarzy psychiatrów 47\% przyznało,że przeciętny obywatel postrzega leczenie psychiatryczne za mało skuteczne bądź nieskuteczne. Ponadto w opinii $46,5 \%$ badanych około $40 \%$ społeczeństwa sądzi, iż psychiatrzy upodabniają się do swoich pacjentów. 56,9\% odpowiadających lekarzy wyznaje,że prestiż psychiatrii w opinii innych specjalności lekarskich jest dużo niższy. Jednak znakomita większość 96,1\% respondentów ma poczucie satysfakcji i zadowolenia z wyboru swojej specjalizacji jednocześnie czując się niedoceniona przez środowisko pracownicze i społeczeństwo (2). Na przestrzeni ostatnich dwudziestu lat specjaliści od zdrowia psychicznego powzięli szereg krajowych i międzynarodowych poczynań przeciwko napiętnowaniu choroby psychicznej. Przedsięwzięcia te, choć w większości skuteczne w zwalczaniu stygmatyzacji i dyskryminacji, są poniekąd krytykowane za brak informacji na temat realiów życia osób $\mathrm{z}$ chorobami psychicznymi i ich rodzin. Zdaniem niektórych krytyków działania antystygmatyzacyjne specjalistów od zdrowia psychicznego były w prawdzie ukrytą próbą unicestwienia stygmatyzacji samej psychiatrii jako zawodu (3). 
Wnioski: Na podstawie otrzymanych wyników można zauważyć uprzedzenie społeczeństwa do pacjentów psychiatryczych, chorób z tej dziedziny oraz samych lekarzy specjalistów. Strach, niepewność i wycofanie może być uwarunkowane nieadekwatnym poziomem wiedzy. $\mathrm{Ku}$ pokrzepieniu, wraz $\mathrm{z}$ upływem lat obserwuje się jednak wzrastające zaufanie społeczeństwa do psychiatrów.

\section{Bibliografia:}

1. Sutovic A. Psychitary between glorification and stygmatization. 2017 Dec; 29(Suppl 5):880-884

2. Kochański A., Cechnicki T. Opinie polskich psychiatrów o psychiatrii i własnej roli zawodowej. 2018; 27 (1): 31-48

3. Schulze Beate. Stigma and mental health professionals: a review of the evidence on an intricate relationship. 2007 Apr;19(2):137-55. 